\title{
An Application of AHP Approach to Evaluate the Brand Equity for Healthcare Center Case in Taiwan
}

\author{
Wan Tran Huang \\ Business Administration dept. of Asia University \\ Taichung City, Taiwan \\ wthuangwantran7589@gmail.com
}

\author{
Tran Trong Thuy \\ Business Administration dept. of Asia University \\ Taichung City, Taiwan \\ lobelchen@yahoo.com.vn
}

\begin{abstract}
In recent years, having a strong brand is important, since it can provide a business with several benefits both externally and internally. In order to have a strong brand, the company's and the customer's perception of the brand equity needs to be congruent. Therefore, the objective of the research is to show out the opinions from company and costumers in terms of brand equity by using the Analytical Hierarchy Process (AHP) as research method.
\end{abstract}

\section{Keywords-AHP; brand equity; preventive healthcare center}

\section{INTRODUCTION}

A company can be seen and examined from different perspectives. Some people correlate the company with the product range while others connect it with its graphical image. The pressure on companies to stand out constantly increases due to the ever-increasing competition. However, companies that successfully manage their brand can expect benefits such as advantage of market entry and differentiation over the competitors (Hatch and Schultz, 2008).

The company becomes more and more understand that a brand's value was not to be underestimated, since a strong brand is possibly the most valuable asset of a company (Keller, 2002). The management world recognized the importance of brands, and soon the focus shifted to understanding their value, vision and purpose. The result was the formation of the concepts known as brand equity (Kapferer, 2008).

Having a strong brand is important. In order to have a strong brand, the company needs to understand what the brand equity for customers, so that the company can develop its business by making a brand that reflects its identity and also can be perceived by customers. Objectives are toanalyze the company opinion in terms of brand equity, andthe customer opinion in terms of brand equity.

\section{LITERATURE REVIEW AND CONCEPTUAL FRAMEWORK}

\section{A. Literature Review}

Brand Equity: In general they have a common topic about investigating the coherency between the brand identity and brand image but happen in different fields (Alexandra R., et al, 2010, Anderson, H. \& Robertson, F. 2008, Becker, P. \& Palmer, S., 2009).

Preventive Healthcare Center: It is about preventive healthcare center and its relation with optimal location to maximize participation(Gu, W. et al., 2010).
AHP theory and its application help the decision-maker facing a complex problem with multiple conflicting and subjective criteria (Werner, D. 2011, Saaty, T.L., 2008)

\section{B. Conceptua Framework}

Brand equity consists of five different asset dimensions: brand loyalty, brand awareness, perceived quality, brand associations, and other proprietary assets such as patents, trademarks and channel relationships (Aaker 1991).

Brand loyalty is a deeply held commitment to re-buy or repatronize a preferred product or service consistently in the future and resist switching to another brand.

Brand awareness is the ability of a potential buyer to recognize or recall that a brand is a member of a certain product category.

Perceived quality is the consumer's perception quality or superiority of a product or service with respect to its intended purpose. It is influencing which brands are included and excluded from the consideration set and which brand is to be selected.

Brand associations are anything that connects the customer to the brand. It divides the assets that build brand equity into four categories: brand loyalty, brand awareness, perceived quality, and brand associations.

\section{RESEARCH METHOD}

There two different ways of doing research, qualitative and quantitative. This research used quantitative research because it wants to precisely measure "consumer behavior, knowledge, opinions, or attitudes" (Cooper and Schindler, 2008). In order to fulfill the chosen objective, the researcher collects data that represent the brand equity of a case company.

\section{Expert Approach}

The expert approach is represented by company employees (top level managers) who considered as an expert in this case company. The purposes of using expert's opinion are to find out real, contemporary information concerning the particular case. It can provide a wide range of information about single case, which brings forward deep and focused insight.

Analytic Hierarchy Process (AHP) as one of Multi Criteria Decision Method (MDCM) families was taken into consideration.AHP methodology is implemented in the software package Expert Choice. 


\section{Survey Method}

The survey method is represented by actual customers of case company. Conducting a customer survey is never a straightforward process.

This customer survey used the same questions with expert approach in order to find out how customers would value brand equity factors and how they would rank each factor with different features. So that researcher could compare the results and identify whether the company's perception of their brand equity has been properly reflected on their consumers.

TABLE 1.THE FUNDAMENTAL SCALE

\begin{tabular}{|c|c|c|}
\hline $\begin{array}{l}\text { Intensity of } \\
\text { importance }\end{array}$ & Definition & Explanation \\
\hline 1 & $\begin{array}{c}\text { Equal } \\
\text { importance }\end{array}$ & $\begin{array}{l}\text { Two activities } \\
\text { contribute equally to the } \\
\text { objective }\end{array}$ \\
\hline 2 & Weak & \\
\hline 3 & $\begin{array}{l}\text { Moderate } \\
\text { importance }\end{array}$ & $\begin{array}{l}\text { Experience and } \\
\text { judgment slightly favor } \\
\text { one activity over } \\
\text { another }\end{array}$ \\
\hline 4 & $\begin{array}{l}\text { Moderate } \\
\text { plus }\end{array}$ & \\
\hline 5 & $\begin{array}{c}\text { Strong } \\
\text { importance }\end{array}$ & $\begin{array}{l}\text { Experience and } \\
\text { judgment strongly favor } \\
\text { one activity over } \\
\text { another }\end{array}$ \\
\hline 6 & Strong plus & \\
\hline 7 & $\begin{array}{l}\text { Very strong } \\
\text { or } \\
\text { demonstrated } \\
\text { importance }\end{array}$ & $\begin{array}{l}\text { An activity is favored } \\
\text { very strongly over } \\
\text { another; its dominance } \\
\text { demonstrated in } \\
\text { practice }\end{array}$ \\
\hline 8 & $\begin{array}{l}\text { Very, very } \\
\text { strong }\end{array}$ & \\
\hline 9 & $\begin{array}{l}\text { Extreme } \\
\text { importance }\end{array}$ & $\begin{array}{l}\text { The evidence favoring } \\
\text { one activity over } \\
\text { another is of the highest } \\
\text { possible order of } \\
\text { affirmation }\end{array}$ \\
\hline
\end{tabular}

Source: Saaty and Vargas (2001), P.6

\section{Data}

\section{Sampling Plan}

The sample size of company employees are 25 respondents and customers are 65 respondents. Because the sample size should be according to the experts so this relatively small number of respondents is acceptable since AHP is an expertbased methodology (Saaty, 1990c).

\section{Data Collection}

The primary data for this research come from the survey at case company. In order to get information concerning the brand equity of case company, researcher did a survey with people in the company management and actual customers..

The survey was conducted by using questionnaire that includes statements about the criteria and sub-criteria of brand equity. The secondary data come from books, internet, journals and articles. Secondary data is obtained from the collection of information from others regarding the key terms of research.

\section{Questionnaire Design}

The ratio scale was developed this way and it is defined as follows in Table 1. The Table 1 is the example of AHP survey template. Note that four items compared to each other need six questions to cover all possibilities. Five items would need ten questions and three items only three questions. The formula to calculate how many questions need to be created is according to Saaty (1990a) with i representing the number of items that are to be compared: $\frac{[t[-1]}{2}$. For instance, for 5 questions the number of required comparison would be $\frac{[\mathrm{E}[5-1]]}{2}=10$.

\section{Data Analysis Procedure}

The data analysis includes the computation of the comparison matrix with Expert Choice Software. After creation of a test survey some respondents were asked to fill out the survey

Next is the priority comparison between company employees and customers, so that can be known whether they interpret the perceptions in the same way or not. Then there is a consistency test by using Cronbach's alpha test. The closer Cronbach's alpha coefficient is to1.0 the greater the internal consistency of the items in the scale. Next is ANOVA test to determine the existence of a statistically significant difference among several group means.

\section{RESULTS}

\section{Analysis of Variance (ANOVA) Test}

SPSS produces many tables in its output from a one-way ANOVA and the summary of the results are shown on Table 4. It is the summary results of the output.

The $p$-value of them are greater than 0.05 , only three results that got p-value lesser than 0.05 then considered as statistically significant. There was significant difference in interest in company opinions between Gender $(\mathrm{P}=0.00)$ and BD (Brand Awareness compared with Brand Associations).It came from company point of view that there is a relation between genders especially female with brand awareness. It means the female managers in the company are more understand how to recognize their company brand. Only one p-value that got significant differences, the others are no significant difference in interest in brand equity between demographic factors. In customer's point of view, there were two results that have a statistically significant interaction $(\mathrm{P}<0.05)$. First, the full time employment significantly correlated with brand loyalty $(\mathrm{P}=0.01)$. Second, the full time employment also significantly correlated with brand awareness $(\mathrm{P}=0.02)$. It means the full employment of customer 
get more understanding about brand loyalty and brand awareness of the case company.

\section{Overall Results from Company Employees}

From level two criteria that consist of: Brand Loyalty, Brand Awareness, Perceived Quality and Brand Associations, the most preferred criterion is Brand Awareness (33.9\%). Followed by Perceived Quality $(27.1 \%)$, Brand Loyalty $(21.3 \%)$ and the lowest one is Brand Associations (17.7\%). Total of the weight of all level two items are $100 \%$.

In order to get the overall priority of in level three items, local weights of each item are needed. Based on the local weights the global weights can be calculated and global ranking can be created. The sum of the global weight percentages from all level three items must be $100 \%$.

Since Brand Awareness scored the highest in level two, its three sub-criteria from five sub-criteria also score high in an overall comparison, which is: Brand Memory (9.5\%), Brand Recall $(8.6 \%)$ and Brand Recognition $(8.1 \%)$.

\section{Overall Results from Customers}

Different from company research result, between level two criteria that consist of: Brand Loyalty, Brand Awareness, Perceived Quality and Brand Associations, the most preferred criterion is Perceived Quality $(26.8 \%)$. Followed by Brand Loyalty (25.6\%), Brand Awareness (24.0\%) and the lowest one is Brand Associations (23.5\%). And the sums of the weight of all level two items are $100 \%$.

The local weights of level two and level three come from the AHP computation from previous chapter. The local weight is important in order to get the overall priority of all items in level three items. So the global weights can be calculated and global ranking can be created based on the local weights. The sum of the global weight percentages from level three items must be $100 \%$.

Since Perceived Quality weight scored the highest in level two of customer research results, its sub-criteria (level three) also score high in an overall comparison. The highest score is Making Perception Match Actual Quality (6.9\%). Followed by Delivering High Quality $(6.5 \%)$ as the third and Price as a Quality Cue (6.3\%) as the fourth. The second rank comes from Brand Loyalty sub-criteria, which is: Liking the Brand (6.6\%).

\section{CONCLUSIONS}

The top five ranks of both company and customer from global ranking of all level three items results, none of them are the same. But surprisingly the company and customer have similarities opinion for the lowest weight of level two criteria, which is Brand Associations, and also for the lowest rank in overall global rank for level three items; it is Non-ProductRelated Attributes.
It means that the company's perception of brand equity still hasn't been interpreted by the customers in the same way. Still have a gap between their perceptions in terms of the most prioritized criteria and sub-criteria of Brand Equity. But the company and customer have same opinion about criteria and sub-criteria that are not prioritized with respect to Brand Equity. The results from this thesis can be interesting for case company in a market where the competition has recently increased significantly and where the brand equity needs to stand out and build a loyal customer base in a way that was not necessary before.

Initially the company thinks they have to prioritize on the following level three items: Brand Memory, Brand Recall, Brand Recognition, Satisfaction Measurement and Product Quality. Because in the beginning of the business the company need to promote their brand and make it can be recognized by customers. However, the consumer results are not the same as mentioned in the company results. The customer more concerned about the quality of service. So after seven years in business, the company needs to change their priority from promotion to service quality because to make customer satisfied with the service that provided is really important. The customer results can be very beneficial to the case company because there are several criteria that a top priority for consumers, which in fact also been considered by the company, but has not become a priority.

\section{REFERENCES}

[1] R. Alexandra. ,"Brand Identity and Brand Image", 2010.

[2] H.. Anderson and F. Robertson,"Swedish Fashion Companies and Brand Associations - a study of the coherency between brand identity and brand image", 2008.

[3] P. Becker and S. Palmer, "Branding in Universities: Identity versus Image - a case study of a Swedish University", 2009.

[4] W. Gu, " Optimization of Preventive Health Care Facility Locations", 2010.

[5] D. Werner, "A Study of Taiwan Car User's Attitudes with an Application of AHP Approach"., 2011.

[6] T.L., Saaty, "Decision Making with The Analytic Hierarchy Process", 2008.

[7] D. Aaker, "Managing Brand Equity: Capitalizing on the Value of a Brand Name. New York": The Free Press, 1991.

[8] K. Keller, "Branding and Brand Equity". Marketing Science Institute. Cambridge, 2002.

[9] J. Kapferer, "The new Strategic Brand management - Creating and sustaining brand equity lang term" 4th edition. Kogan Page Limited. Cornwall,GreatBritain,2008.

[10] M.J., Hatch and M. Schultz, "Taking Brand Initiative". Jossey-Basse publication, San Fansisco, 2008.

[11] T.L. Saaty, “ The Analytic Hierarchy Process: Planning, priority setting, resource allocation" (2nded.). New York; London: McGraw-Hill International Book Co, 1990a.

[12] T.L. Saaty and L.G. Vargas, "Model, methods, concepts \& applications of the analytic hierarchy process". Boston: Kluwer Academic Publisher, 2011 . 